\title{
HUMAN RESOURCE DEVELOPMENT: EXPERIMENTAL CHECK OF THE EFFICIENCY OF THREE EDUCATIONAL TECHNOLOGIES
}

\author{
Walery Okulicz-Kozaryn \\ Pedagogical University of Cracow, Poland
}

CMESTE

JEL Category: 015, I21, M53

\begin{abstract}
Human resource development related to training, education, and development of each person. The purpose of the study was to compare the efficiency of three educational technologies for the human resources development. The didactic and non-didactic efficiency of three basic educational technologies (traditional, game and research) was experimentally analyzed. The results were proved experimentally: the didactic efficiency of traditional educational technology is between $3 \%$ and $5 \%$; the didactic efficiency of the game educational technologies is 30 ... 35\%; the efficiency of the research educational technologies is more than $100 \%$. Based on the results of the study, it is necessary to refuse from the traditional educational technologies - they have the lowest efficiency. The game educational technologies and the research educational technologies provide a higher level of didactic and nondidactic results than the traditional educational technologies. These two educational technologies are recommended for human resources development. It is reasonable to assume that the results of the research should be applied in every school and in every university, which deals with the human resources development. The purpose of the next study is a detailed description of the game educational technologies.
\end{abstract}

Keywords: human resource management, human resource development, efficiency, educational systems, educational technology

\section{INTRODUCTION}

The ability of the society is to react to inner and outer changes and deal with its regulation mechanisms which depend on the quality of the education systems.

This paper is interesting from two points of view:

Address of the corresponding author:

Walery Okulicz-Kozaryn

䒠=” v-kazarin@narod.com
- on the one hand, the results of the study should be used to improve the quality of the educational systems;

- on the other hand, the widespread using of the obtained results leads to positive qualitative changes in the human resource management and development.

The purpose of the study is to compare the efficiency of three educational technologies for the human resources development. 
Two educational technologies were selected and recommended for widespread use as a result of the study.

\section{METHODOLOGY}

While the exactly used methodologies vary from field to field, the overall process is the same. The scientific methods to search for conditions of effective training, education, and development of pupils, students and adults were used.

This study was accomplished in the direction: literature review, the experiments and the analysis of results.

The literature review was started in 2002.

Under the term, "efficiency" author means the ratio of residual knowledge to the originally specified amount. We can say this indicator is 'didactic efficiency'.

The experiments were started in 2002 when the monitoring of information resources was continuing. The experiments were conducted by well-documented and powerful methods of analysis (BUS_9641, 2009). A considerable number of pupils, students and adults was covered by the test.

Since 2009 author started to combine experimentation and practical application of the results. This discovery brought money to continue the study. The feedback helped in the implementation of the results. Therefore, in 20162017 new wonderful results were obtained.

In this investigation, there are four sources for good results.

Firstly. The procedure which was used for data collection was similar to the one of the most studying.

Secondly. The material that was used was partially based on classical learning theory. The rest was our good educational practice.

Thirdly. The method of the study that was used different significantly from the methods used by the majority of the scientists. Most scientists are studying specific details of the separate educational technology. Here was compared the educational efficiency of three basic educational technologies. It was decided that the best method of analyzing for this investigation was to add a comparison of the efficiency of the type of railway locomotive and the type of energy technologies.

And, finally. The major source is that dramatic increase in the efficiency of the human resources development, we are looking for in the aims of education. There were educational technologies that adequately meet the aims of human resources development as the challenges of modern society.

The growth of non-didactic results was recorded by the method of the pedagogical supervision.

All the methods were economically justified.

\section{RESULTS}

The results of the literature review and three examples are represented below.

\subsection{Literature review}

As outlined in the study, the author took the idea (Okulich-Kazarin V., 2008) that the educational technologies were identical to the railway technologies and the energy technologies.

The didactic efficiency of the game educational technologies and the traditional educational technologies was equal to $31.5 \%$ and $5.0 \%$. It coincides with the values of efficiency in the railway transport technologies and the energy technologies, please, see the table in the paper (Okulich-Kazarin V., 2008).

Further, the author conducted supplementary information research. According to these results the line "ultra-high efficiency" was added. Now, this is a new table (see table 1).

The efficiency of the energy systems in the form of the heating furnace was identified as 'low' in table 1 (efficiency $=3 \% \quad \ldots \quad 5 \%$ ). The railway transport technologies have the same result (steam locomotive). The traditional training was similar to the heating furnace in the educational technologies. Its efficiency was proved experimentally by Smagin V. and Khristenko V. in the laboratory works and it applies to 'low' also (Slastenin, V., 2000). 
Table 1. A comparison of the efficiency of educational technologies with the type of railway locomotive and the type of the energy technologies

\begin{tabular}{|c|c|c|c|}
\hline $\begin{array}{c}\text { Efficiency } \\
\%\end{array}$ & $\begin{array}{c}\text { Name of } \\
\text { educational } \\
\text { technology }\end{array}$ & $\begin{array}{l}\text { Type of } \\
\text { railway } \\
\text { locomotive }\end{array}$ & $\begin{array}{c}\text { Name of } \\
\text { energy } \\
\text { technology }\end{array}$ \\
\hline $\begin{array}{c}\text { low: } \\
3 \ldots 5 \%\end{array}$ & traditional & $\begin{array}{c}\text { steam } \\
\text { locomotive }\end{array}$ & $\begin{array}{l}\text { heating } \\
\text { furnace }\end{array}$ \\
\hline $\begin{array}{c}\text { medium: } \\
30 \ldots 35 \%\end{array}$ & $\begin{array}{c}\text { game } \\
\text { (interactive) }\end{array}$ & $\begin{array}{c}\text { diesel } \\
\text { locomotive }\end{array}$ & $\begin{array}{c}\text { heating } \\
\text { power station }\end{array}$ \\
\hline $\begin{array}{c}\text { high: } \\
90 \ldots 98 \%\end{array}$ & self-study & $\begin{array}{c}\text { electric } \\
\text { locomotive }\end{array}$ & $\begin{array}{c}\text { MHD } \\
\text { generating }\end{array}$ \\
\hline $\begin{array}{l}\text { ultra high: } \\
>100 \%\end{array}$ & research & $?$ & $\begin{array}{l}\text { nuclear } \\
\text { station }\end{array}$ \\
\hline
\end{tabular}

The medium efficiency (efficiency $=30 \% \ldots 35 \%$ ) was had by the heating power plant in the energy systems. The railway transport technologies have the same result (diesel locomotive). The efficiency of training using the educational game also was 'medium' (30\% ... 35\%).

The high efficiency (efficiency $=90 . .98 \%$ ) was characterized by magnetohydrodynamic (MHD) generators in energy technologies. The railway transport technologies have the same result (electric locomotive). This high efficiency corresponds to the technology of self-study in the educational systems. A self-study is used in the asynchronous model of distance learning.

The ultra-high efficiency featured in energy technologies. This technology is associated with the production of heat and electrical energy in the nuclear stations. There is some additional energy in the result.

The research educational technologies have similar efficiency to nuclear stations. There is an additional knowledge gained during the research study.

That's why the research technologies are widely used at the Universities. So, it is written on the website of the University of Cambridge: 'Our programs are based on active learning principles they include projects, discussion, exercises, cases and use of IFM tools to bring theory to life and enable practice' (http://www.jobs.ac.uk). Many universities (Asia, Europe, America) have a button 'RESEARCH' on their websites, for example:
- $\quad$ http://www.sakarya.edu.tr;

- $\quad$ http://pols.bilkent.edu.tr;

- http://www.uc3m.es;

- $\quad$ http://www.cb.cityu.edu.hk;

- $\quad$ http://www.uchicago.edu

Also, on 16 Jan 2018, it was organized the scientific seminar "Models of research training" in the national research University "Higher School of Economics" (Moscow, Russian Federation) for the pupils. More details can be found at https://ioe.hse.ru/expresspolls/poll/213541514.ht $\mathrm{ml}$.

Table 1 demonstrates that the game educational technologies are more efficient than the traditional educational technologies between 5 and 9 times. It means that the Teacher using the game educational technologies automatically becomes more effective for the human resources development than another Teacher who uses the traditional educational technologies.

The educational technologies of self-study are more efficient than the traditional educational technologies in between 15 and 24 times. It is very good for the human resources development and learning. Unfortunately, the self-study educational technologies are limited at schools.

Therefore, we will not consider these educational technologies further.

Maximum of the didactic efficiency is in the research educational technologies. These educational technologies are more efficient than the traditional educational technologies more than 25 times. And the efficiency of the research educational technologies is higher than the efficiency of the game educational technologies approximately between 3 and 4 times.

The research educational technology enables to develop the human resources. It is the technology that develops science, economy, and industry of every State.

The author had to establish whether educational technologies lead us to the goals that were supplied by the human resources development.

Let's go back to the purposes of the education systems, which have been set by society (Emblidge, M., et al., n.d.; Chen-Fong Wu, 2014). Please note that these goals were not didactic. 
They cannot be estimated using the didactic efficiency. However, society put such purpose prior to the educational systems. And people had to find out which of the educational technologies were adequate for these purposes.

Next table demonstrates compliance of the nondidactic goals and the possibilities of the three educational technologies: traditional, game, and research (see table 2). The technologies of selfstudy were not considered here due to their weak application at schools.

Table 2. What goals can be achieved with the use of the educational technologies?

\begin{tabular}{|c|c|c|}
\hline Traditional & $\begin{array}{c}\text { Game } \\
\text { (interactive) }\end{array}$ & Research \\
\hline \multicolumn{3}{|c|}{ technology operations and concepts } \\
\hline \multicolumn{3}{|c|}{$\begin{array}{c}\text { critical thinking, problem-solving and decision } \\
\text { making }\end{array}$} \\
\hline \multicolumn{3}{|c|}{ digital citizenship and information fluency } \\
\hline- & \multicolumn{2}{|c|}{ creativity } \\
\hline- & \multicolumn{2}{|c|}{ communication and collaboration } \\
\hline- & \multicolumn{2}{|c|}{ modern citizenship competency } \\
\hline- & - & innovation \\
\hline- & - & research \\
\hline
\end{tabular}

As illustrated in Table 2, the usual lesson in the traditional educational technologies allows achieving three non-didactic goals only.

The game educational technologies allow us to achieve six non-didactic goals.

And finally, the research educational technologies allow us to achieve eight non-didactic goals. In other words, the research educational technologies allow achieving all of the public purposes described in the works (Emblidge, M., et al., n.d.; Chen-Fong Wu, 2014).

Both parts of the literature review showed the advantages of the game educational technologies and, especially, the research educational technologies. The efficiency of the game educational technologies is higher than the efficiency of the traditional educational technologies dramatically. The efficiency of the research educational technologies is the highest.

\subsection{Results of the experiments}

There are practical results confirming the high didactic and non-didactic efficiency of the game educational technologies and the research educational technologies. In this section, the author did not describe the experiments in detail, as it was described in the earlier papers.

My remarkable results of the experimentation confirm literature data described above.

\section{The first example.}

Here the author showed the achievement of the didactic goals and the non-didactic goals as 'communication and collaboration' (see table 2). It was shown for the school children through the game educational technologies.

The author made the experiment in a regular school in 2008. Among pupils in grade 8 were formed 2 groups of 15 pupils. The main criterion for the formation of the groups was the result of the study of the pupils for the last period on the basis of all the Sciences. It was equal to 4.0. Thus, the average outcome in the two groups had the same value, equal to 4.0 .

After that, the first group of pupils (let's call it the 'game' group) had 12 lessons with the game technologies. In the second group (let's call it 'traditional') such lessons were not given.

Next, all pupils were studied by the traditional method by the same Teachers. They studied the same program, the same textbooks.

Finally, two months later, they were examined again by their Teachers. The average results of education were compared for two groups of our pupils. The results of all the Sciences were compared.

The result for the first (game) group was higher than for the second (traditional) group by $23 \%$. What did lead to such a didactic difference?

There were twelve lessons with the game educational technologies for the first group earlier.

The growth of such results as 'communication and collaboration' (see table 2) is noted for the first (game) group. 
In this experiment, the author recorded increase of the following non-didactic results for the pupils of the first group:

- The ability to think logically - the growth was $16.1 \%$ (from 3.48 at the beginning of the experiment to 4.04 at the end of the experiment);

- The ability to work with information - the growth was $12.5 \%$ (from 3.85 at the beginning of the experiment to 4.33 at the end of the experiment);

- The ability to plan - the growth was $10.8 \%$ (from 3.80 at the beginning of the experiment to 4.10 at the end of the experiment);

- The ability to organize personal work - the growth was $14.4 \%$ (from 3.47 at the beginning of the experiment to 3.97 at the end of the experiment).

These non-didactic results cannot be obtained during the lesson by traditional educational technology.

Thus, the experiment clearly showed that the game educational technologies increase didactic and non-didactic learning outcomes critically.

The second example.

Here the author showed the achievement of the non-didactic goal as 'creativity' (see table 2 ) by the research educational technologies.

The achievement of the goal of 'creativity' was looked through the zoom 'factor of the originality' students.

In 2002 the author recorded growth of the 'factor of the originality' by $21.3 \%$ in the learning process of the students of 'Management in tourism' by the research educational technologies.

Thus, my experiment showed that the research technologies give the achievement of such nondidactic goal that cannot be achieved through the traditional educational technologies.

The third example.

Here the author showed the achievement of the non-didactic goal as 'research' (see table 2) by the research educational technologies.

The author made an experiment for three semesters in 2016-2017. Here it was showed the achievement of non-didactic goal as 'research' with the research educational technologies.

It was a comparison of the efficiency of the two technologies: the traditional educational technology and the research educational technology (see table 3).

The author used the research educational technology in the first semester. The experiment involved five groups of between 20 and 25 students. It was 100-125 students at this experimental stage.

The author used traditional educational technology in the second semester. The experiment involved seven groups of between 20 and 25 students. It was 140-175 students at this experimental stage.

The author used scientific educational technology in the third semester. The experiment involved five groups of between 20 and 25 students. It was 100 125 students at this experimental stage.

The criterion of the efficiency was the number of publications of students during the semester.

Table 3. A comparison of the efficiency of the traditional educational technologies and the scientific educational technologies

\begin{tabular}{|c|c|c|c|}
\hline $\begin{array}{c}\text { Year } \\
\text { (semester) }\end{array}$ & $\begin{array}{c}\text { Number of } \\
\text { groups }\end{array}$ & $\begin{array}{c}\text { Educational } \\
\text { technology }\end{array}$ & $\begin{array}{c}\text { Number of } \\
\text { publications }\end{array}$ \\
\hline $\begin{array}{c}2015-2016 \\
\text { (summer) }\end{array}$ & 5 & Research & $\mathbf{1 7}$ \\
\hline $\begin{array}{c}2016-2017 \\
\text { (winter) }\end{array}$ & 7 & Traditional & 5 \\
\hline $\begin{array}{c}2016-2017 \\
\text { (summer) }\end{array}$ & 5 & Research & 16 \\
\hline
\end{tabular}

Table 3 shows that the result of the scientific educational technology is higher than the result of the traditional educational technology three times. It should be added that a greater number of publications were prepared by a smaller number of students. The proportion of students who participated in the scientific research and in the writing publications were:

- more than $13,6 \%$ in the summer semester 2015-2016 (the research educational technologies),

- $\quad 2,8-3,6 \%$ in the winter semester 2016-2017 (the traditional educational technologies), 
- more than $12,8 \%$ in the summer semester 2016-2017 (the research educational technologies).

Thus, the experiment showed that the research educational technologies give the achievement of non-didactic goals that cannot be achieved through the traditional educational technologies.

The children, students and adults like the game educational technologies and research educational technologies very much.

It is difficult to disaccustom children, students and adults from the traditional educational technologies for the first few days. The need to think for yourself scares students at first. After few days, the children, students, and adults are accustomed to intellectual activity. And they start to like it.

The long-term training with the game educational technologies and the research educational technologies generates intellectually active alumni. These are two effective educational technologies for the human resources development.

\section{CONCLUSIONS}

The purpose of the study is achieved. The efficiency of educational technologies was evaluated by modern methods of investigation.

The author compared the efficiency of three educational technologies for the human resources development:

\section{WORKS CITED}

BUS_9641_Business_Statistics_5M (2009). Lecture notes for the Program "Masters of Business Administration". NY: Kingston University. $106 \mathrm{p}$.

Emblidge, M., Ward, E., Brewster, T., Castro, I., Johnson, Krupicka, K., McLaughlin, V., Moore, \& K., Saslaw, E. (n.d.). Educational Technology Plan for Virginia 2010-2015. 100 p. Retrieved from doe.virginia.gov: http://www.doe.virginia.gov/support/technology/edtech_plan/plan.pdf

Okulich-Kazarin, V. (2008). Technical system at the service of education. Siberian educational journal, (4), 416417.

Slastenin, V., Isaev, I., \& Mishchenko, A. (2000). Pedagogy: a textbook for students of pedagogical educational institutions. Moscow: School-Press, 512 p.

Wu, C.-F. (2014, July). The relationship between the embedded instruction approach and modern citizenship competency. TOJET: The Turkish Online Journal of Educational Technology, 13(3), 222-231. 
Received for publication: $\quad 09.01 .2018$

Revision received: $\quad$ 07.06.2018

Accepted for publication: $\quad 22.06 .2018$

\section{How to cite this article?}

Style - APA Sixth Edition:

Okulicz-Kozaryn, W. (2018, July 15). Human Resource Development: Experimental Check of the Efficiency of Three Educational Technologies. (Z. Cekerevac, Ed.) MEST Journal, 6(2), 82-88. doi:10.12709/mest.06.06.02.10

Style - Chicago Sixteenth Edition:

Okulicz-Kozaryn, Walery. 2018. "Human Resource Development: Experimental Check of the Efficiency of Three Educational Technologies." Edited by Zoran Cekerevac. MEST Journal (MESTE) 6 (2): 82-88. doi:10.12709/mest.06.06.02.10.

Style - GOST Name Sort:

Okulicz-Kozaryn Walery Human Resource Development: Experimental Check of the Efficiency of Three Educational Technologies [Journal] // MEST Journal / ed. Cekerevac Zoran. - Toronto : MESTE, July 15, 2018. - 2 : Vol. 6. - pp. 82-88.

Style - Harvard Anglia:

Okulicz-Kozaryn, W., 2018. Human Resource Development: Experimental Check of the Efficiency of Three Educational Technologies. MEST Journal, 15 July, 6(2), pp. 82-88.

Style - ISO 690 Numerical Reference:

Human Resource Development: Experimental Check of the Efficiency of Three Educational Technologies. Okulicz-Kozaryn, Walery. [ed.] Zoran Cekerevac. 2, Toronto : MESTE, July 15, 2018, MEST Journal, Vol. 6, pp. 82-88. 